\title{
ANALISIS EFEKTIVITAS PENGELOLAAN MODAL KERJA GUNA MENINGKATKAN SISA HASIL USAHA PADA KOPERASI PELANGI SAUMLAKI KABUPATEN KEPULAUAN TANIMBAR
}

\author{
Yosentus Olsuin
}

Sekolah Tinggi Ilmu Ekonomi Saumlaki, yosentus.o@gmail.com

\begin{abstract}
ABSTRAK
Kemakmuran masyarakat diamanatkan dalam Undang-Undang Dasar Republik Indonesia 1945 pasal 33 ayat (1) menyatakan bahwa, perekonomian disusun sebagai usaha bersama berdasarkan atas asas kekeluargaan. Koperasi adalah salah satu wadah ekonomi yang bertujuan untuk kesejahteraan seluruh anggota.

Koperasi Pelangi Saumlaki yang menjalankan usaha simpan pinjam belum mengadakan pengelolaan sumber dan penggunaan modal kerja berdasarkan prinsip-prinsip manajemen keuangan yang baik, karena dari data dan informasi yang diperoleh memperlihatkan bahwa dalam 3 (tiga) tahun terakhir dari tahun 2016 samapai tahun 2018 terjadi fluktuasi di dalam perolehan sisa hasil usaha. Mencermati kondisi perkembangan tersebut, nampaknya ada indikasi bahwa pengelolaan modal kerja unit usaha simpan pinjam belum membaik. Penelitian ini bertujuan untuk mengetahui efektivitas pengelolaan modal kerja dapat meningkatkan sisa hasil usaha pada Koperasi Pelangi Saumlak.
\end{abstract}

\section{Kata kunci : efektivitas pengelolaan modal kerja}




\section{ISSN : 2656-3363 - VoL.3. NO.1 2021}

\section{PENDAHULUAN}

Di dalam undang-undang Dasar Republik Indonesia 1945 telah diamanatkan khususnya pasal 33 ayat (1) yang menyatakan bahwa, perekonomian disusun sebagai usaha bersama berdasarkan atas asas kekeluargaan dan menegaskan kemakmuran masyarakatlah yang diutamakan bukan kemakmuran orang seorang.

Sebagai salah satu wadah ekonomi yang menunjang kegiatan hidup orang banyak, maka koperasi dituntut untuk dapat mengembangkan dirinya sejajar dengan perusahaan swasta maupun perusahaan milik pemerintah, dengan harapan koperasi yang sedemikian mampu menampung dan merangkul sebanyak mungkin anggota sebagaimana yang tersirat dalam UUD 1945. Karena itu, pengembangan wadah ekonomi yang satu ini diperlukan suatu pengelolaan yang mantap dan terkoordinir, terutama dalam memanfaatkan sumbersumber dana yang tersedia

karena akan berpengaruh pada besar kecilnya Sisa Hasil Usaha (SHU) yang diperoleh. Memang koperasi tidak bertujuan untuk memperoleh keuntungan, namun koperasi harus mempunyai kemampuan untuk berkembang.

Menyadari pentingnya peran serta koperasi dalam pembangunan ekonomi masyarakat, maka dibentuklah koperasi- koperasi baik di desa, di kota, baik oleh instansi swasta maupun instansi pemerintah termasuk dalam kesatuan-kesatuan dalam lingkungan militer. Salah satu koperasi yang dibentuk untuk maksud dan tujuan dimaksud adalah Koperasi Pelangi Saumlaki. Sebagai salah satu badan usaha diwajibkan pula melakukan pencatatan terhadap seluruh transaksi keuangan yang terjadi yang pada akhirnya dirangkum dan disusun dalam laporan keuangan yang terdiri dari neraca dan laporan SHU.

Pengembangan usaha koperasi secara keseluruhan sangat tergantung pada pengelolaan modal kerja koperasi, karena penggunaan modal kerja yang bersumber dari modal sendiri maupun pinjaman (modal asing) akan menyebabkan terjadinya penurunan aktiva lancar yang dimiliki, maka dalam laporan tentang perubahan modal kerja akan memberikan gambaran tentang bagaimana manajemen mengelola perputaran atau sirkulasi modal secara baik.

Berdasarkan uraian di atas, maka jika dihubungkan dengan Koperasi Pelangi Saumlaki yang menjalankan usaha simpan pinjam nampak bahwa koperasi belum mengadakan pengelolaan sumber dan penggunaan modal kerja berdasarkan prinsip-prinsip manajemen keuangan yang baik. Dari data dan informasi yang diperoleh memperlihatkan bahwa dalam 3 (tiga) tahun terakhir ini terjadi fluktuasi di 


\section{ISSN : 2656-3363 - VoL.3. NO.1 2021}

dalam perolehan sisa hasil usaha. Pada tahun 2016 SHU yang diperoleh sebesar Rp. 19.809.269, naik menjadi Rp. 31.181.304 pada tahun 2017 dan turun lagi menjadi Rp. 21.140.477 pada tahun 2018. Pada sisi lain terjadi peningkatan pada hutang lancar (Modal Eksteren), di mana pada tahun 2016 sebesar Rp. 352.822.712 naik menjadi Rp. 420,290,093 pada tahun 2017 dan naik lagi menjadi Rp. 470,409,786 pada tahun 2018. Namun di sisi lain modal Intern mengalami fluktuasi yaitu pada tahun 2016 Rp. 44.783.111, naik menjadi Rp. 63,999,020 pada tahun 2017 dan turun lagi menjadi Rp.

52.887.546 pada tahun 2018 .

\section{TINJAUAN PUSTAKA}

Fungsi pembelanjaan dalam perusahaan harus searah dengan fungsi lainnya sebab bila ada hambatan pada salah satu fungsi, maka semua fungsi akan mengalami hal yang sama. Dengan demikian maka dapat dikatakan bahwa semua fungsi dalam suatu perusahaan saling terikat dan merupakan suatu sistem yang utuh dan terpadu.

Pengertian modal kerja secara mendalam terkandung dalam konsep modal kerja, maka berikut ini akan di berikan tiga konsep pengertian modal kerja yang di kemukakan oleh Kasmir (2012: 250) sebagai berikut :
1.Konsep Kuantatif adalah modal kerja adalah seluruh aktiva lancar. Dalamkonsep ini adalah bagaimana mencukupi kebutuhan dana untuk membiyaiaoperasi perusahaan jangka pendek. Konsep ini sering di sebut denganmodal kerja kotor (grss working capital).

2.Konsep kualitatif, merupakan konsep yang menitik beratkan kepada kualititas modal kerja. Konsep ini melihat selisih antara jumlah aktiva lancar dengan kewajiban lancar. Konsep ini di sebut modal kerja bersihatau (net working capital).

3. Konsep fungsional, yaitu menekankan kepada fungsi dana yang di miliki perusahaan dalam memperoleh laba. Artinya sejumlah dana yang di miliki dan di gunakan perusahaan untuk meningkatkan laba perusahaan.semakin banyak dana yang di gunakan sebagai modal kerja seharusnya dapat meningkatkan perolehan laba. Demikian pula sebaliknya, jika dana yang digunakan sedikit, laba pun akan menurun.

Pengertian modal kerja ini sejalan dengan Bambang Riyanto, (2011:57-58) yaitu :

1.Konsep kuantitatif, Konsep ini mendasarkan pada kuantitas dari dana yang tertanam dalam unsur-unsur aktiva lancar di mana aktiva ini merupakan aktiva yang sekali berputar kembali 


\section{ISSN : 2656-3363-VoL.3. NO.1 2021}

dalam bentuk semula atau aktiva di mana yang tertanam di dalamnya akan dapat bebas lagi dalam waktu yang pendek. Dengan demikian modal kerja menurut konsep ini adalah "keseluruhan dari jumlah aktiva lancar". Modal kerja dalam pengertian ini sering disebut sebagai modal kerja bruto (gross working capital).

2.Konsep kualitatif yaitu modal kerja yang dikaitkan dengan besarnya jumlah hutang lancar atau hutang yang harus segera dibayar. Dengan demikian maka sebagian dari aktiva lancar ini harus disediakan untuk memenuhi kewajiban finansiil yang harus segera dilakukan, dimana bagian aktiva lancar ini tidak boleh digunakan untuk membiayai operasinya perusahaan karena untuk menjaga likuiditasnya. Modal kerja dalam pengertian ini sering disebut modal kerja neto(net working capital).

3.Konsep Fungsionil, Konsep ini mendasarkan pada fungsi dari dana dalam menghasilkan pendapatan (income). Setiap dana yang dikerjakan atau digunakan dalam perusahaan adalah dimaksudkan untuk menghasilkan pendapatan. Adasebagian dana yang digunakan dalam suatu periode accounting tertentuyang seluruhnya langsung menghasilkan pendapatan bagi periode tersebut (current income) dan ada sebagian dana lain yang juga digunakan selama periode tersebut tetapi tidak seluruhnya digunakan untuk menghasilkan current income.

\section{Mengenai macam-macam modal kerja dalam perusahaan menurut Bambang Riyanto, (2011:61) yaitu:}

1.Modal Kerja Permanen(Permanent Working Capital)Yaitu modal kerja yang harus tetap ada pada perusahaan untuk dapat menjalankan fungsinya, atau dengan kata lain modal kerja yang secara terus menerus diperlukan untuk kelancaran usaha.

Modal kerja permanen dapat dibedakan menjadi :

a)Modal kerja primer(Primary Working Capital). Yaitu jumlah modal kerja minimum yang harus ada pada perusahaan untuk menjamin kontinuitas usahanya.

b)Modal kerja normal(Normal Working Capital). Yaitu jumlah modal kerja yang diperlukan untuk menyelenggarakanluas produksi yang normal.

2.Modal Kerja Variabel(Variabel Working Capital)Yaitu modal kerja yang berubah-ubah sesuai dengan perubahan keadaan,dan Modal kerja ini dibedakan antara :

a)Modal kerja musiman(Seasonal Working Capital). Yaitu modal kerja yang jumlahnya berubah- ubah 


\section{ISSN : 2656-3363-VoL.3. NO.1 2021}

disebabkan karena fluktuasi musim.

\section{METODE PENELITIAN}

b)Modal kerja siklis(Cyclical Working

Capital).Yaitu modal kerja yang jumlahnya berubah-ubah disebabkan karena fluktuasi konjungtor.

c) Modal kerja darurat(Emergency

Working Capital). Modal kerja yang besarnya berubah-ubah karena adanya keadaan darurat yang tidak diketahui sebelumnya.

Secara unmum dapat dikatakan bahwa rentabilitas adalah kemampuan perusahaan menghasilkan laba dari sejumlah dana yang dipakai untuk mengambil keputusan tentang masalah finansial leverage, yaitu apakah di dalam memenuhi kebutuhan dana perusahaan akan menggunakan modal sendiri atau ataukah modal asing.

Menurut Bambang Riyanto (2011:59) bahwa: "Rentabilitas suatu perusahaan menunjukan perbandingan antara laba dengan aktiva atau modal yang menghasilkan laba tersebut."

Menurut Munawir (2010:33) bahwa: "Rentabilitas adalah kemampuan perusahaan menghasilkan laba selama periode tertentu."

Jadi dari berbagai pendapat diatas, dapat disimpulkan rentabilitas adalah perbandingan antara laba dengan modal yang menghasilkan laba tersebut.

Penelitian ini masuk jenis deskriptif dimana penelitian dilakukan untuk mengumpulkan data dan fakta-fakta perusahaan yang berhubungan erat dengan objek penelitian kemudian dianalisis berdasarkan kaidahkaidah ilmu pengetahuan yang relevan.

\section{A. Lokasi Penelitian}

Lokasi Penelitian ini di Koperasi Pelangi Saumlaki, Kecamatan Tanimbar Selatan Kabupaten Kepulauan Tanimbar.

\section{B. Model Penelitian}

Model penelitian yang digunakan dalam rancangan penelitian ini adalah "deskriptif kuantitatif', di mana peneliti berusaha mengolah data keuangan yang diambil di lapangan selanjutnya dianalisis untuk mendapatkan kesimpulan sebagai jawaban atas pertanyaan-pertanyaan penelitian.

\section{Rancangan Penelitian}

Mengukur variabel pengaruh maupun variabel terpengaruh dengan menggunakan indikator- indikator sebagai berikut :

a. Variabel bebas yaitu modal kerja yang 


\section{ISSN : 2656-3363-VoL.3. NO.1 2021}

diukur dengan indikator : Pengelolaan Aktiva dan Pengelolaan Passiva

b. Variabel Terikat yaitu SHU yang diukur dengan indikator : Pendapatan dan Biaya- biaya

\section{HASIL DAN PEMBAHASAN}

\section{Hasil Penelitian}

Hasil analisis di atas dilakukan menggunakan program Eviews 11 dengan menghasilkan model estimasi. Terlihat dari hasil analisis di atas, terdapat beberapa hal dari hasil analisis yang saya rincikan sebagai berikut.

1. Dependent variabel: Y. Menjelaskan bahwa dalam penelitian ini menggunakan Y sebagai variabel dependenpen atau terikat.

2. Method: Panel Least Square. Menjelaskan metode yang digunakan untuk analisis, yang mana panel least square adalah fixed effect model.

3. Sample: 2016 - 2018. Menunjukkan series waktu yang digunakan dalam kajian.

4. Periods included: 3. Merupakan banyaknya/lamanya/series tahun dalam penelitian.

Pengujian Terhadap Koefisien Regresi Secara Parsial (Uji t)

Analisis ini digunakan untuk mengukur kekuatan dua variabel atau lebih dan juga menunjukan arah hubungan antara variabel dependen dengan variabel independen. Adapun rumus dari regresi linier sederhana secara umum adalah: $\mathrm{Y}=\mathrm{a}$ $+\mathrm{bX}$

Berdasarkan hasil Uji t, maka pengambilan keputusannya adalah sebagai berikut:

Berdasarkan hasil perhitungan data menggunakan program Eview 11. diperoleh hasil bahwa nilai signifikansi sebesar 0.7945. Ini berarti X berpengaruh signifikan terhadap Y karena nilai signifikansi lebih besar dari 0,05 dengan arah hubungan positif.

Berdasarkan hasil pengujian dengan metode regresi linier sederhana untuk menguji pengaruh variabel independen (X) terhadap variabel dependen (Y) maka dapat disusun sebuah persamaan sebagai berikut:

$Y=C(1)+C(2) * X$
$Y=9682580+0.030660 * X$

Hasil tersebut dapat dijelaskan sebagai berikut : Koefisien regresi $\mathrm{X}$ adalah sebesar 0.030660 yang berarti bahwa setiap peningkatan $\mathrm{X}$ sebesar $1 \%$ akan menaikan $\mathrm{Y}$ sebanyak $0.030660 \%$ dengan asumsi variabel lain konstan, begitu juga sebaliknya.

Pengujian Terhadap Koefisien Regresi Secara Simultan (Uji F)

Pengujian hipotesis uji $\mathrm{F}$ digunakan untuk melihat apakah secara keseluruhan variabel bebas mempunyai pengaruh yang bermakna terhadap variabel terikat. 


\section{ISSN : 2656-3363-VoL.3. NO.1 2021}

Hasil pengolahan data terlihat bahwa variabel independen (X1 dan X2) signifikansi F hitung sebesar 0.111929 dengan tingkat signifikansi yang lebih besar (0.794465) dari 0,05. Dengan demikian hasil analisis dalam penelitian ini menunjukkan bahwa secara bersama- sama variabel independen $(\mathrm{X})$ berpengaruh terhadap $\mathrm{Y}$. Dengan demikian dapat dikatakan bahwa modal kerja yang dikelola secara efektif dapat meningkatkan Sisa Hasil Usaha.

Koefisien Determiasi Berganda.

Nilai koefisien determinasi berganda dalam eviews 11 sama seperti halnya dengan aplikasi lainnya yaitu di beri label R-Square. Dalam tabel diatas dapat dilihat bahwa RSquare sebesar 0.100662 yang berarti sekumpulan variabel devendent di dalam model dapat menjelaskan variabel indevendent sebesar $10.0662 \%$. sedangkan sisanya dijelaskan oleh variabel lain diluar model yang tidak diteliti.

Adjusted R Square

Nilai adjusted $\mathrm{R}$ Square artinya nilai $\mathrm{R}$ Square yang telah terkoreksi oleh nilai standar error. Dalam tabel diatas adjuster R Square sebesar -0.798675. sedangkan nilai standart error model regresi 0,6217093 ditunjukkan dengan label S.E Of regression. Nilai standar error ini lebih besar dari pada nilai standart deviasi variabel independent yang dijuntukkan dengan label "S.D. dependent var" yaitu sebesar 0,6217093 yang diartikan bahwa model regresi valid sebagai model dependent variabel.

\section{Kesimpulan}

Dari Hasil tersebut dapat dijelaskan sebagai berikut : Koefisien regresi $\mathrm{X}$ adalah sebesar 0.030660 yang berarti bahwa setiap peningkatan X sebesar $1 \%$ akan menaikan Y sebanyak $0.030660 \%$ dengan asumsi variabel lain konstan, begitu juga sebaliknya.

Pengujian Terhadap Koefisien Regresi Secara Simultan (Uji F)

Pengujian hipotesis uji $\mathrm{F}$ digunakan untuk melihat apakah secara keseluruhan variabel bebas mempunyai pengaruh yang bermakna terhadap variabel terikat.

Hasil pengolahan data terlihat bahwa variabel independen (X1 dan X2) signifikansi F hitung sebesar 0.111929 dengan tingkat signifikansi yang lebih besar (0.794465) dari 0,05. Dengan demikian hasil analisis dalam penelitian ini menunjukkan bahwa secara bersama- sama variabel independen $(\mathrm{X})$ berpengaruh terhadap $\mathrm{Y}$. Dengan demikian dapat dikatakan bahwa modal kerja yang dikelola secara efektif dapat meningkatkan Sisa Hasil Usaha.

Koefisien Determiasi Berganda.

Nilai koefisien determinasi berganda dalam eviews 11 sama seperti halnya dengan aplikasi lainnya yaitu di beri label R-Square. Dalam tabel diatas dapat dilihat bahwa RSquare sebesar 0.100662 yang berarti 


\section{ISSN : 2656-3363-VoL.3. NO.1 2021}

sekumpulan variabel devendent di dalam model dapat menjelaskan variabel Pengendalian Laba. Penerbit UPP STIM indevendent sebesar $10.0662 \%$. sedangkan YKPN :YOGYAKARTA sisanya dijelaskan oleh variabel lain diluar model yang tidak diteliti.

Adjusted R Square

Nilai adjusted $R$ Square artinya nilai $R$ Square yang telah terkoreksi oleh nilai standar error. Dalam tabel diatas adjuster R Square sebesar -0.798675 . sedangkan nilai standart error model regresi 0,6217093 ditunjukkan dengan label S.E Of regression. Nilai standar error ini lebih besar dari pada nilai standart deviasi variabel independent yang dijuntukkan dengan label "S.D

\section{DAFTAR PUSTAKA}

Assauri, S. 2004. Manajemen Produksi dan Operasi. Fakultas Ekonomi Universitas Indonesia. Jakarta

Astuti, H. Kanti. 2006. "Analisis tentang Pengendalian Persediaan dalam Perusahaan". Jurnal Ekonomi dan Manajemen Vol.7 (1) : 41-51. From:

Bambang Riyanto. (2011),Dasar-dasar Pembelanjaan Perusahaan, BPFE:Yogyakarta. ...

Kasmir. (2012), Analisis Laporan Keuangan, PT. Raja Grafindo Persada: Jakarta.

Munawir, S.( 2010), Analisis laporan

Keuangan, Edisi keempat,Cetakan

Kelima Belas, Liberty:Yogyakarta.

Undang-Undang Dasar Republik Indonesia 1945

Adisaputro, Anggarini, 2007. Anggaran

Bisnis, Analisa Perencanaan dan 